\title{
THE NOVEMBER MEETING IN IOWA CITY
}

The three hundred forty-fifth meeting of the Society was held at the State University of Iowa on Friday and Saturday, November 26-27, 1937. At this meeting there were in attendance about one hundred persons, among whom were the following fifty-six members of the Society:

E. S. Allen, B. M. Armstrong, J. V. Atanasoff, G. A. Bliss, L. M. Blumenthal, H. R. Brahana, W. C. Brenke, C. C. Camp, H. H. Campaigne, E. W. Chittenden, L. M. Coffin, N. B. Conkwright, A. H. Copeland, A. T. Craig, W. M. Davis, H. H. Goldstine, Cornelius Gouwens, L. M. Graves, G. L. Gross, G. A. Herr, R. A. Higdon, J. J. L. Hinrichsen, D. L. Holl, M. H. Ingraham, Dunham Jackson, D. E. Kearney, I. F. Keeler, R. B. Kershner, S. C. Kleene, E. H. Larguier, M. I. Logsdon, J. V. McKelvey, Dorothy Manning, R. J. Michel, E. E. Moots, J. L. Nagle, E. N. Oberg, G. B. Price, W. C. Randels, W. T. Reid, J. F. Reilly, H. L. Rietz, P. G. Robinson, W. J. Rusk, R. G. Sanger, E. R. Smith, R. C. Stephens, E. B. Stouffer, W. J. Trjitzinsky, Henry Van Engen, R. W. Wagner, L. E. Ward, W. G. Warnock, K. W. Wegner, K. P. Williams, Roscoe Woods.

The meeting opened Friday afternoon with a session for contributed papers followed by an address by Professor W. J. Trjitzinsky, of the University of Illinois, entitled Singular point problems in the theory of linear differential equations. Saturday morning Professor A. H. Copeland, of the University of Michigan, spoke on Fundamental concepts of the theory of probability, and the meeting closed with another session for short papers.

One of the features of the meeting was a session in the old Iowa State Capitol, a building of marked architectural distinction.

On Friday evening a dinner was held at the Memorial Union. About seventy-five mathematicians and their guests attended. Professor H. L. Rietz acted as toastmaster and called first upon Professor Dunham Jackson. Dean E. B. Stouffer then spoke on the problems presented to mathematics by the reorganization of the college curriculum which would be necessary if the present first two years of college work were turned over to the high schools. Professor G. A. Bliss expressed the feeling that the meetings which are most enjoyable and of greatest value to the members attending them are the smaller meetings, such as the one at Iowa City, at which one can attend the entire scientific program and at which there is ample time for the discussion of each paper.

Professor E. W. Chittenden presided at the general session on Friday, and Professor W. C. Brenke at the lecture. Professor E. R. 
Smith was chairman at the lecture on Saturday morning, and Professor L. E. Ward at the session which followed. At the end of the first session on Friday afternoon Professor J. F. Reilly read a statement concerning Professor R. P. Baker, of the University of Iowa, who recently died.

The titles of papers read at the meeting follow. Those whose abstract numbers are followed by $t$ were read by title. Mr. J. H. Daoust was introduced by Professor Dunham Jackson, Professor Gerhard Tintner by Professor E. R. Smith, Mr. C. E. Sealander by Professor L. E. Ward, Mr. Fulton Koehler by Professor Dunham Jackson, Mr. F. D. Rigby by Professor E. W. Chittenden, and Dr. E. H. Rothe by Professor M. H. Ingraham. Papers 1-8 were presented Friday afternoon and papers 9-17 on Saturday morning.

1. On the weak summability of Fourier series, by W. C. Randels. (Abstract 43-11-393.)

2. On certain constants associated with Bernstein's theorem, by J. H. Daoust. (Abstract 43-11-401.)

3. On a van der Corput absolute constant, by R. B. Kershner. (Abstract 43-11-403.)

4. On the correlation of a mean and standard deviation in small samples drawn from a certain non-normal population, by H. L. Rietz. (Abstract 44-1-2.)

5. On correlation due to common elements, by A. T. Craig. (Abstract 44-1-1.)

6. A dynamic theory of duopoly, by Gerhard Tintner. (Abstract 44-1-5.)

7. Some implicit function theorems in the large, by G. M. Ewing. (Abstract 43-11-398-t.)

8. Topological proofs of uniqueness theorems in the theory of differential and integral equations, by E. H. Rothe. (Abstract 43-11-423.)

9. On a family of curves associated with a conjugate net, by P. O. Bell. (Abstract 43-11-399-t.)

10. A particular third order irregular boundary value problem (preliminary report), by C. E. Sealander. (Abstract 44-1-4.)

11. The characterization of pseudo- $S_{2, r}$-sets, by L. M. Blumenthal. (Abstract 43-11-397.)

12. Note on orthogonal polynomials in three variables, by Dunham Jackson. (Abstract 43-11-400.)

13. Orthogonal polynomials on a square, by Fulton Koehler. (Abstract 43-11-402.)

14. Note on the axioms for Boolean algebras, by F. D. Rigby. (Abstract 44-1-3.) 
15. Additional notes on the inversion of the Laplace transformation, by R. V. Churchill. (Abstract 43-11-394-t.)

16. A quadratic form problem in the calculus of variations, by A. A. Albert. (Abstract 43-11-395-t.)

17. Weakly complete Banach spaces, by H. H. Goldstine. (Abstract 43-11-396-t.)

M. H. INGRAHAM, Associate Secretary

\section{THE NOVEMBER MEETING IN PASADENA}

The three hundred forty-sixth meeting of the American Mathematical Society was held at the California Institute of Technology on Saturday, November 27, 1937. The chair was occupied at various times by Professors E. R. Hedrick, G. C. Evans, and E. T. Bell. The attendance of about fifty included the following thirty-one members of the Society:

L. D. Ames, H. A. Arnold, H. M. Bacon, Clifford Bell, E. T. Bell, Myrtie Collier, P. H. Daus, R. P. Dilworth, C. H. Dix, G. C. Evans, H. E. Glazier, J. W. Green, D. W. Hall, N. A. Hall, H. J. Hamilton, E. R. Hedrick, C. G. Jaeger, Glenn James, W. E. Mason, A. D. Michal, T. M. Putnam, W. C. Risselman, A. A. Shaw, D. V. Steed, S. E. Urner, F. A. Valentine, Morgan Ward, M. B. White, W. M. Whyburn, E. R. Worthington, Max Zorn.

Luncheon for members and their guests was served at the Athenaeum of the California Institute of Technology.

The titles of papers read at the meeting follow. Those whose abstract numbers are followed by the letter $t$ were read by title.

1. Some theorems on subsequences, by H. J. Hamilton. (Abstract 43-11-404.)

2. Abstract residuation over lattices, by $\mathrm{R}$. P. Dilworth. (Abstract 43-11-405.)

3. A formal expansion theory for functions defined by two variable power series, by N. A. Hall. (Abstract 43-11-406.)

4. A property of harmonic functions in three variables, by $\mathrm{J} . \mathrm{W}$. Green. (Abstract 43-11-407.)

5. Properties of invariant sets under pointwise periodic homeomorphisms, by D. W. Hall and G. E. Schweigert. (Abstract 43-11-408.)

6. A new fragment of Euclid's "Elements" (preliminary report), by A. A. Shaw. (Abstract 43-11-409.)

7. On the first case of Fermat's last theorem, by Glenn James. (Abstract 43-11-410.) 